\title{
POLLEN MORPHOLOGY OF AMYGDALUS L. (ROSACEAE) IN IRAN
}

\author{
${ }^{*}$ MAHNAZ VAFADAR $^{1}$, FARIDEH ATtAR $^{1}$, Hosein MAROOFI $^{2}$, MANSUR MiRTADZADINI $^{3}$ \\ ${ }^{1}$ Central Herbarium of University of Tehran, \\ School of Biology, Faculty College of Science, University of Tehran \\ Po. Box: 14155-6455, Tehran, Iran \\ *e-mail: vafa@khayam.ut.ac.ir \\ ${ }^{2}$ Research Center of Agriculture and Natural Resources, Kurdistan Province \\ Po. Box: 66169-36311-714, Sanandaj, Iran \\ ${ }^{3}$ Department of Biology, Faculty of Science, \\ Shahid Bahonar University, Kerman, Iran
}

(Received: June 25, 2009. Accepted: July 29, 2009)

\begin{abstract}
Pollen grain of 16 species and three hybrids of the genus Amygdalus L., representing two subgenera and two sections distributed in Iran were examined by light and scanning electron microscopy. All pollen grains are tricolporate. The shape of grains varies from subprolate through prolate. Regarding outline, in polar view, pollen grains are triangular-circular and in equatorial view, elliptic. Regarding sculpturing of exine, the frequent type like many members of family Rosaceae is striate with or without perforations that can be subdivided into three subtypes: type I (A-B), type II (A-B) and type V. In three species, A. trichamygdalus, A. spinosissima and A. orientalis, exine sculpture type is completely different. In the first species is rugulate, in the second species is reticulate and in $A$. orientalis, it is gemmate-perforate. Ornamentation of ridges (muri) in the striate sculpture is parallel to ectocolpus. Number of perforations in tectum, diameter of them, striae intervals and the thickness of ridges varies among studied taxa. The striae have different depth and slope. Results showed that among pollen grain characters, shape is useful character solely for separating of taxonomic ranks in Iranian Amygdalus specially in subgeneric or section level.
\end{abstract}

KEY WORDS: Pollen morphology, Amygdalus, Rosaceae, Taxonomy, Iran.

\section{INTRODUCTION}

The genus Amygdalus $\mathrm{L}$. is one of the genera of tribe Amygdaleae, subfamily Spiraeoideae (formerly subfamily Prunoideae) in Rosaceae (Potter et al. 2007). This genus with approximately $40-45$ species in the world is mainly distributed in SW Asia and C Asia but a few species are distributed in E Asia (China and Mongolia) and SE Europe (Browicz and Zohary 1996). The main phytogeographical region for Amygdalus distribution is Irano-Touranian region. According to Browicz (1969) (15 species and two hybrids) and the addition to this genus by Khatamsaz (1993) (21 species and six hybrids in which seven species, one variety and all six hybrids are endemic taxa for flora of Iran.), Iran is the main center for distribution of this genus and in fact, this is one of the most important elements of Elburz and Zagros mountains, steppes, mountains and semidesert localities in Iran. Amygdalus is one of the most problematic genera in family Rosaceae and taxonomy of this genus like many other genera in family Rosaceae such as: Crataegus L., Pyrus L., Cotoneaster Medik., Rosa L. and Rubus L. deals with numerous problems because of high degree of variation in morphological characters under different ecological conditions (Khatamsaz 1993). It shows high degree of variation within one species, high hybridization inter species and high homoplasy under ecological conditions. Because all former taxonomic classifications of Iranian species of Amygdalus were based on morphological characters soley and this examination in Amygdalus shows high variation and does not provide sufficient data for delimitation of species, so the boundaries between species in this genus are not clear. On the other hand, we need more data sources including molecular, biochemical and micromorphological data for taxonomical resolution and evaluation of relationships among species in this genus. Against morphological characters, micromorphological characters are more constant and provide efficient, reliable and detailed data for distinguishing taxonomic relation- 
ships. A comparative study on pollen morphology of Prunoideae of China has been investigated by Zhou et al. (1999). Several other researchers studied the pollen morphology of rosaceous members including Reitsma (1967), Ueda and Tomita (1989), Hebda and Chinnappa (1990a, b), Bednorz et al. (2005) and Dönmez (2008). Present research is the first study on pollen grain morphology of Iranian species of Amygdalus. The main aim of this paper is to present a detailed study on pollen morphology of Iranian species of Amygdalus and then to use the results of pollen features for evaluating of taxonomic relationships among Amygdalus species in Iran.

\section{MATERIAL AND METHODS}

Pollen grains of 16 species and three hybrids of the genus Amygdalus from Iran were studied by light and scanning electron microscopy. Pollen grains were removed from herbarium specimens deposited in the Central Herbarium of University of Tehran (TUH). Voucher specimens of this study are listed in Table 1. For LM, fresh pollen samples were acetolysed following the method described by Erdtman (1952). The pollen grains were mounted in glycerine jelly on glass slides after acetolysis. Slides for LM were studied with an Olympus microscope model BX-50 and photographed with a Nikon camera model $200 \mathrm{M}$. About 20 pollen grains were used for these measurements. The results are presented in Table 2. For SEM, the specimens after acetolysis were mounted on $12.5 \mathrm{~mm}$ diameter stubs and then

TABLE 1. Voucher specimens of Iranian species of Amygdalus used in Pollen grain study.

\begin{tabular}{|c|c|c|}
\hline Species & Collection data & Collectors \\
\hline A. arabica Olivier & $\begin{array}{l}\text { Kurdistan: } 30 \mathrm{~km} \text { to Kamiaran from Sanandaj, } \\
\text { 36311-TUH }\end{array}$ & Attar, Maroofi \& Zamani \\
\hline A. communis $\mathrm{L}$. & $\begin{array}{l}\text { Kurdistan: Kamiaran to Marivan, } \\
\text { Takht-zangi village, 36306-TUH }\end{array}$ & Attar, Maroofi \& Zamani \\
\hline A. eburnea Spach. & Kerman: Baft, Gugher village, 32101 -TUH & Mirtadzadini \\
\hline A. elaeagnifolia Spach subsp. elaeagnifolia & $\begin{array}{l}\text { Chahar Mahal-e Bakhtiari: Iz-e to Shahr-e Kurd, } \\
15 \mathrm{~km} \text { to Iz-e, 19008-TUH }\end{array}$ & Ghahreman \& Attar \\
\hline A. elaeagnifolia Spach subsp. leiocarpa (Boiss.) Browicz & Fars: Shiraz to Abadeh, After Saadat Shahr, 37128-TUH & Vafadar \& Kazemi \\
\hline A. erioclada Bornm. & Fars: $15 \mathrm{~km}$ to Pasargad from Abadeh, 37130-TUH & Vafadar \& Kazemi \\
\hline A. glauca Browicz & Fars: kotal Pir-e Zan, 8622-TUH & Mobayen \\
\hline A. haussknechtii (C. K. Schneider) Bornm. var. pubescens Bornm. & $\begin{array}{l}\text { Kurdistan: } 15 \mathrm{~km} \text { to Kamiaran, } \\
\text { Morvarid pass, } 36027-\mathrm{TUH}\end{array}$ & Attar, Maroofi \& Zamani \\
\hline A. korshinskyi (Hand.-Mazz.) Bornm. & Kurdistan: $20 \mathrm{~km}$ to Sanandaj from Marivan, 36315-TUH & Attar, Maroofi \& Zamani \\
\hline A. kotschyi Boiss. \& Hohen. & Kurdistan: $20 \mathrm{~km}$ to Sanandaj from Marivan, 36029-TUH & Attar, Maroofi \& Zamani \\
\hline A. lycioides Spach var. horrida (Spach) Browicz & Tehran: Road of Karaj to Chalus, Pourkan, 37183-TUH & Attar \& Zamani \\
\hline A. lycioides Spach var. lycioides & Kurdistan: 20 km to Sanandaj from Marivan 36314-TUH & Attar, Maroofi \& Zamani \\
\hline A. orientalis Duh. & Kermanshah: $35 \mathrm{~km}$ to Eivan-e Gharb, 37231-TUH & Attar, Vafadar \& Zamani \\
\hline A. reticulata Runemark ex Khatamsaz & Fars: Shiraz, Bamou National Park, 37125-TUH & Vafadar \& Kazemi \\
\hline A. scoparia Spach & Fars: Dasht-e Ardzan, 37135-TUH & Vafadar \& Kazemi \\
\hline A. spinosissima Bge. subsp. turcomanica (Lincz.) Browicz & $\begin{array}{l}\text { North Khorassan: } \\
10 \mathrm{~km} \text { to Bojnnourd from Shirvan, 37181-TUH }\end{array}$ & Attar \& Zamani \\
\hline A. trichamygdalus (Hand.-Mazz.) Woronow & $\begin{array}{l}\text { Kurdistan: } \\
\text { Kamiaran to Marivan, Takht-zangi village, 36308-TUH }\end{array}$ & Attar, Maroofi \& Zamani \\
\hline A. wendelboi Freitag & Sistan and Baluchistan: Taftan mountain, 37819 -TUH & Mirtadzadini \\
\hline A. Xiranshahrii Khatamsaz & Kerman: Dalfard, 38287-TUH & Mirtadzadini \\
\hline A. ×kamiaranensis Khatamsaz \& Assadi & Kurdistan: Kamiaran, 36312-TUH & Attar, Maroofi \& Zamani \\
\hline A. $\times$ keredjensis Browicz & Tehran: Karaj, Koohdashteh, 37186-TUH & Attar \& Zamani \\
\hline
\end{tabular}




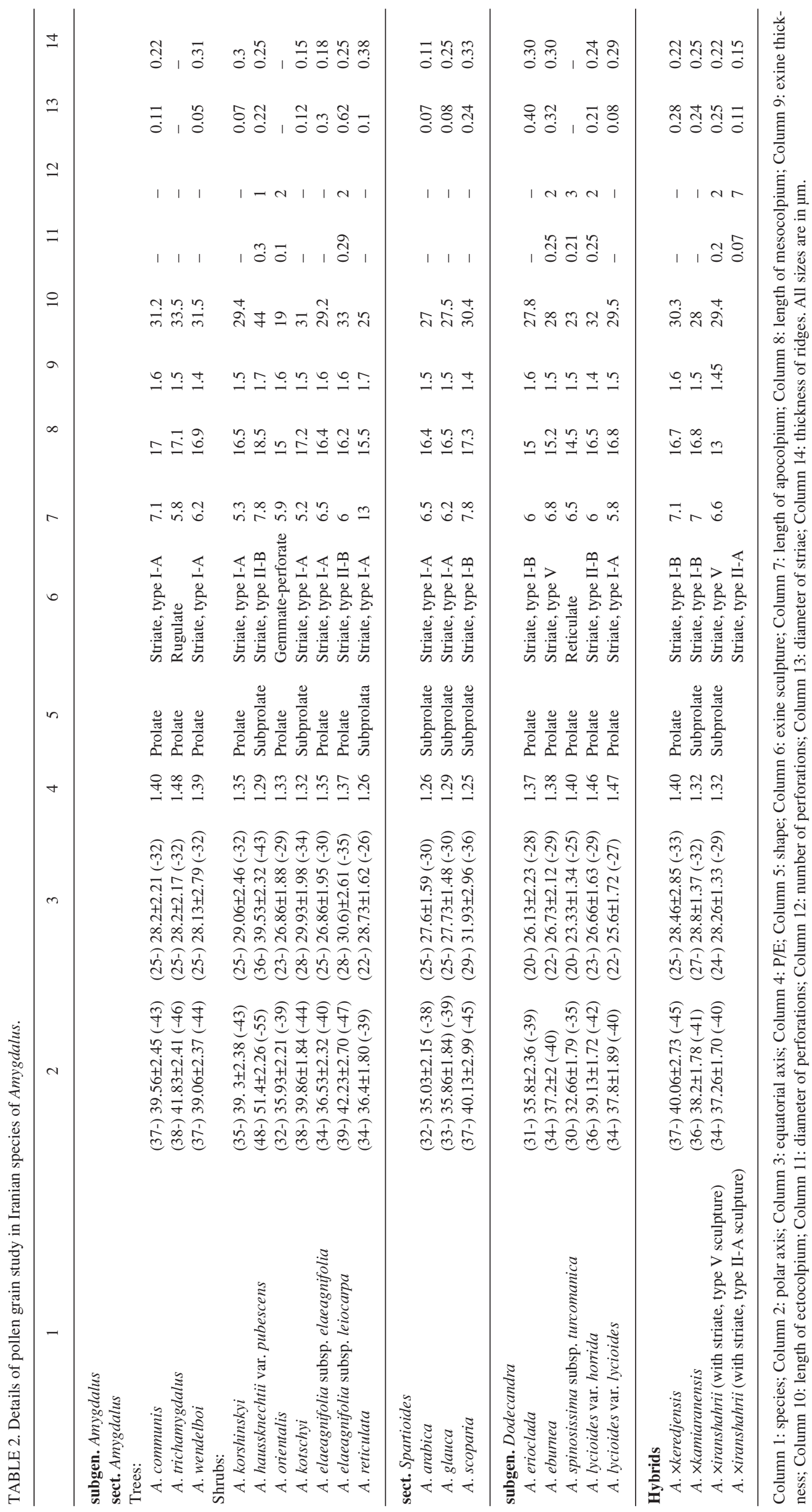


coated in a sputter coater with $25 \mathrm{~nm}$ of gold-paladium at an accelerating voltage of $10-15 \mathrm{kv}$. The specimens were examined and photographed with Leo SEM-440I and Tscan SEM-Vega. The terminology follows that of Punt et al. (2007), Halbritter et al. (2007), Erdtman (1952), Ueda and Tomita (1989) and Hebda and Chinnappa (1990).

\section{RESULTS}

General pollen grain

features

The main features of the studied pollen grains are listed in Table 2 and LM and SEM Figures of pollen grains are presented in Figs 1-35. Studied pollen grains of Amygdalus are symmetric isopolar monads. Regarding outline, in polar view, pollen grains are triangular-circular and in equatorial view are elliptic. All pollen grains are tricolporate including three ectocolpi and three endopori. Ectocolpi are long but narrow at two ends and arranged in a regular longitudinal pattern. The width of ectocolpus is variable, usually wider in equatorial region. The sculpture of ectocolpus is different from the exine surface, similar to psilate. Each endopore is placed in the middle part of the ectocolpus. Exine is two-layered. Exine thickness ranges from thin to average class (column 9 in Table 2). The shape of pollen grains (column 5 in Table 2 ) varies from subprolate $(\mathrm{P} / \mathrm{E}=1.25$ -1.32) through prolate $(\mathrm{P} / \mathrm{E}=1.33-1.48)$ The mean of polar axis (column 2 in Table 2) varies from $32.66 \mu \mathrm{m}$, in A. spinosissima subsp. turcomanica to $51.4 \mu \mathrm{m}$ in A. haussknechtii var. pubescens. The mean of equatorial axis (column 3 in Table 2) varies from $23.33 \mu \mathrm{m}$, in A. spinosissima subsp. turcomanica to $39.53 \mu \mathrm{m}$, in A. haussknechtii var. pubescens. The mean of $\mathrm{P} / \mathrm{E}$ ratio (column 4 in Table 2), ranges from 1.25, in A. scoparia and to 1.48, in A. trichamygdalus.

Regarding exine sculpture (column 6 in Table 2), the main exine sculpture type is striate according to Punt et al. (2007), Halbritter et al. (2007), Ueda and Tomita (1989) and Hebda and Chinnappa (1990). The last two references have focused on pollen morphology in family Rosaceae and its genera, specially Ueda and Tomita (1989) have considered several subtypes for striate type that are applicable for the sculpture types in the studied species in this research. Regarding to it, striate type can be subdivided into some subtypes that the sculpture of pollen grains in this research comprises of these subtypes: type I (A-B), type II (A-B) and type V. Among studied species, on of the hybrids, A. Xiranshahrii includes two different exine sculpture types (Figs 34 and 35).

\section{Exine sculpture types}

\section{A. Striate, type I (A-B)}

This exine sculpture type deals with striate pollen, which has clear fingerprint-like ridges. Two exine patterns are recognized within this type; type I-A with short interval of ridges and type I-B with long interval of ridges (Ueda and Tomita 1989). In Iranian Amygdalus, type I-A is observed in these species: A. communis, A. wendelboi, A. korshinskyi, A. kotschyi, A. elaeagnifolia subsp. elaeagnifolia, A. reticulata, A. arabica, A. glauca and A. lycioides var. lycioides (Figs 6, 9, 13, 16, 18 and 28). Exine sculpture in $A$. scoparia, A. erioclada, A. ×keredjensis and A. ×kamiaranensis is striate, type I-B (Figs 20, 21, 30 and 32).

\section{B. Striate, type II (A-B)}

Striate, type II differs from type I by having prominent perforations. This type is subdivided into two subtypes: IIA with short intervals between ridges and II-B with long intervals (Ueda and Tomita 1989). In A. Xiranshahrii, two exine sculpture types are observed, in which one type is striate, type II-A (Fig. 35). Also in A. haussknechtii var. pubescens, A. elaeagnifolia subsp. leiocarpa and A. lycioides var. horri$d a$, sculpturing is striate, type II-B (Figs 10, 14 and 26).

\section{Striate, type V}

This type has obscure ridges due to moderate slope of ridges (Ueda and Tomita 1989). In A. eburnea and $A$. xiranshahrii (another sculpture), type of exine sculpture is type V (Figs 23 and 34).

\section{Other exine sculpture types}

In three studied taxa, exine sculpture is completely different from striate type. In A. trichamygdalus, it is rugulate (Fig. 8), in A. spinosissima subsp. turcomanica, exine sculpture is reticulate (Fig. 24) and in A. orientalis, it is gemmate-perforate (Fig. 12).

Ornamentation of striae is parallel to each other. Striae are usually narrow and in some cases, there are perforations in their bottom. Ridges (muri) are narrow, cylindrical and parallel to polar axis. Perforations are circular or elliptic. Diameter of perforations (column11 in Table 2) ranges from $0.07 \mu \mathrm{m}$ in A. Xiranshahrii (pollen with striate, type II-A) to $0.3 \mu \mathrm{m}$ in A. haussknechtii var. pubescens. Number of perforations (column12 in Table 2) in $1 \mu^{2}$ ranges from 1 in A. haussknechtii var pubescens to 7 in A. Xiranshahrii (pollen with striate, type II-A). Striae intervals (column 13 in Table 2) varies from $0.05 \mu \mathrm{m}$ in A. wendelboi to $0.62 \mu \mathrm{m}$ in A. elaeagnifolia subsp. leiocarpa. Thickness of ridges (column14 in Table 2) ranges from o.11 $\mu \mathrm{m}$ in $A$. arabica to $0.38 \mu \mathrm{m}$ in $A$. reticulata.

\section{DISCUSSION}

In this paper, we describe the detailed morphological characters of pollen grains of the genus Amygdalus in Iran. 16 species and three hybrids of Iranian species of Amygdalus used for the pollen morphology study. According to Browicz (1969) and Khatamsaz (1993), Iranian Amygdalus is classified into two subgenera (subgen. Amygdalus and subgen. Dodecandra (Spach) Browicz). The first subgenus comprises two sections: sect. Amygdalus and sect. Spartioides Spach. The first section includes 12 species in two vegetative subgroups: trees and shrubs. Common morphological feature of all species in this section is the presence of brachyblast (short shoots). The tree subgroup in this section include three species that distributed in the west, northwest and south Iran. Among them, A. wendelboi is an endemic species for the flora of Iran (Khatamsaz 1993). Nine species are included in the shrubby subgroup that among them, six species were studied in this research. Most of the species in this subgroup are found in the west and northwest and two species in the center and south Iran. Among nine species, four species are endemic elements for Iran including A. haussknechtii (C. K. Schneider) Bornm., A. pabotii Browicz, A. elaeagnifolia Spach and A. reticulata (Runemark ex Khatamsaz) (Khatamsaz 1993). 

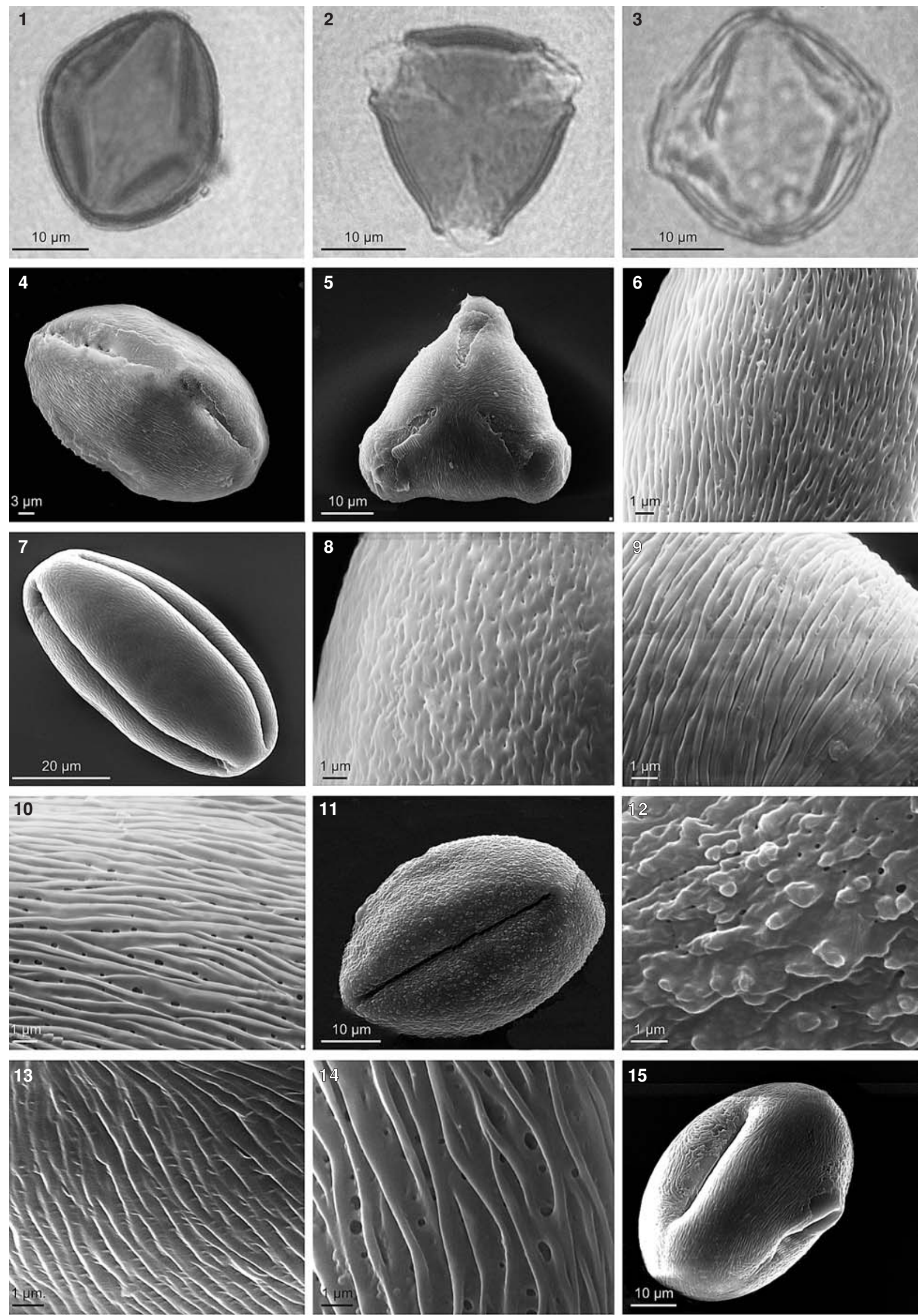

Figs 1-15. LM and SEM micrographs of pollen grains in Iranian species of Amygdalus. 1-3. LM micrographs: (1) A. communis, (2) A. elaeagnifolia subsp. leiocarpa (3) A. spinosissima subsp. turcomanica. 4-15. SEM micrographs: (4-6) A. communis, (7, 8) A. trichamygdalus, (9) A. wendelboi, (10) A. haussknechtii var. pubescens, $(11,12)$ A. orientalis, (13) A. elaeagnifolia subsp. elaeagnifolia, (14) A. elaeagnifolia subsp. leiocarpa, (15) A. reticulata. (7) scale bar $=20 \mu \mathrm{m} ;(1,2,3,5,11,15)$ scale bar $=10 \mu \mathrm{m} ;(6,8,9,10,12,13,14)$ scale bar $=1 \mu \mathrm{m}$. 

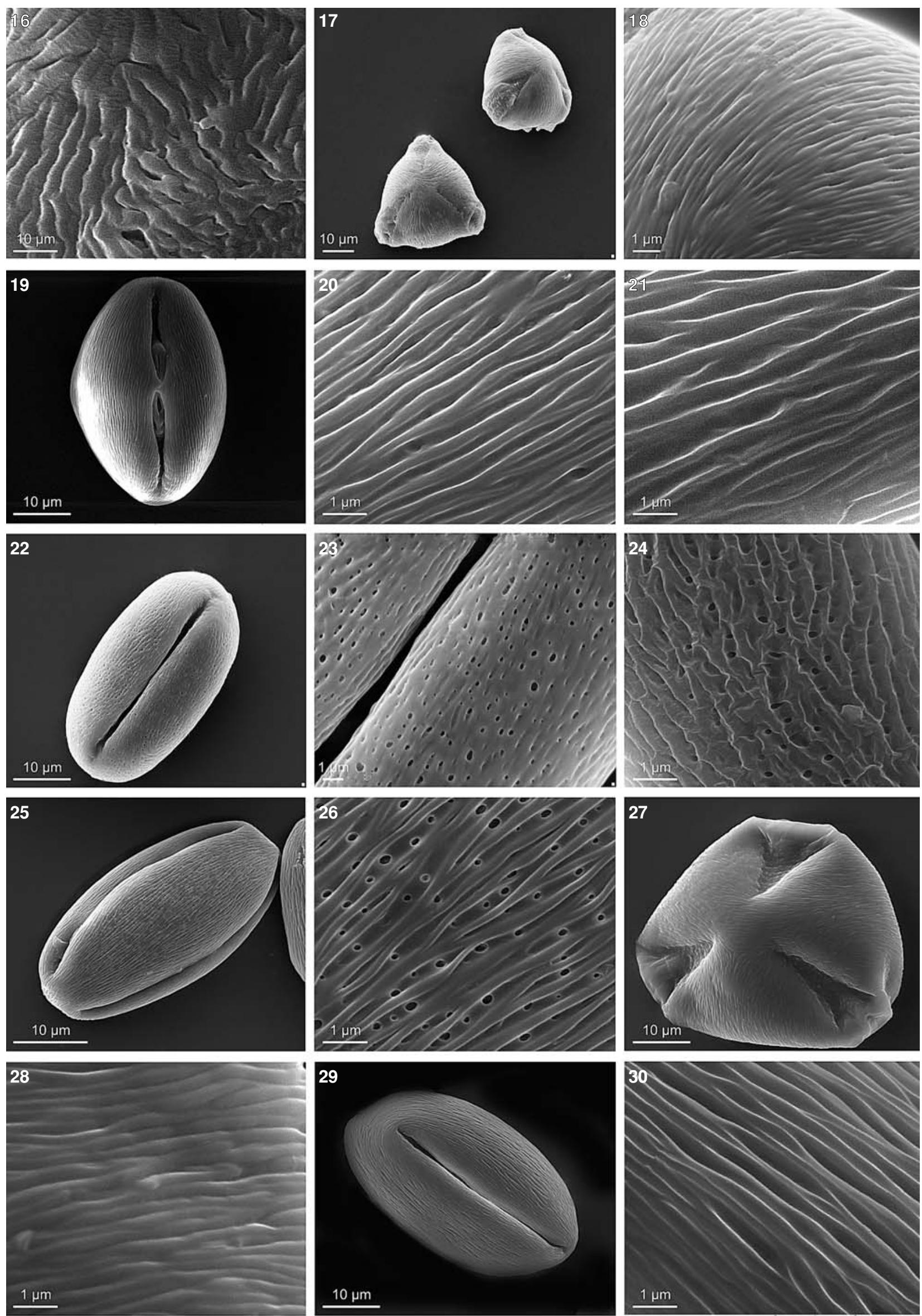

Figs 16-30. SEM micrographs of pollen grains in Iranian species of Amygdalus. (16) A. reticulata, (17, 18) A. arabica, (19, 20) A. scoparia, (21) A. erioclada, (22, 23) A. eburnea, (24) A. spinosissima subsp. turcomanica, $(25,26)$ A. lycioides var. horrida, $(27,28)$ A. lycioides var. lycioides, $(29,30)$ A. $\times k e r e-$ djensis. $(16,17,19,22,25,27,29)$ scale bar $=10 \mu \mathrm{m} ;(18,20,21,23,24,26,28,30)$ scale bar $=1 \mu \mathrm{m}$. 

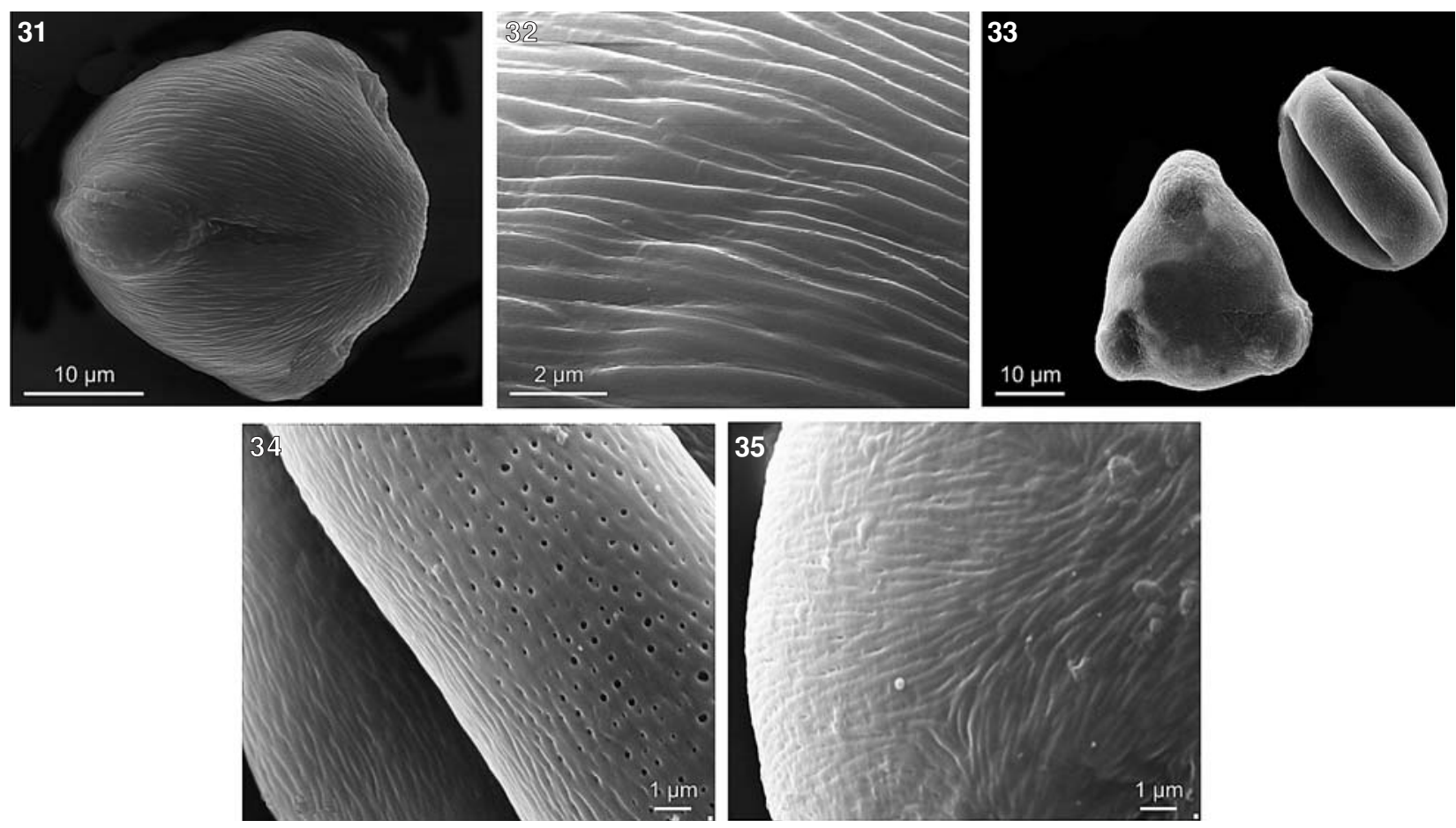

Figs 31-35. SEM micrographs of pollen grains in hybrids of Amygdalus: $(31,32)$ A. ×kamiaranensis, (33-35) A. xiranshahrii, two exine sculpture types. $(31,33)$ scale bar $=10 \mu \mathrm{m} ;(32)$ scale bar $=2 \mu \mathrm{m} ;(34,35)$ scale bar $=1 \mu \mathrm{m}$.

The second section in the first subgenus, sect. Spartioides includes three junciform species without brachyblast that found in different localities and habitats. Among them, A. glauca Browicz is an endemic species for the flora of Iran in the south of the country (Browicz 1969; Khatamsaz 1993). Also, A. scoparia is one of the most widespread species of Amygdalus in Iran.

The second subgenus (subgen. Dodecandra) is not classified to section level and includes six shrubs that from morphological point of view are completely different from the first one. They are spiny shrubs with thick spines. These species are found in Iran in the east, west, northwest, south and center. Among them, A. lycioides (with two varieties) is another widespread species of Amygdalus in Iran. A. eburnea Spach and one variety of A. lycioides Spach (var. horrida (Spach) Browicz) are endemic elements (Khatamsaz 1993).

The main pollen characters of Amygdalus are occurrence of three colpi and pori, elliptic outline in equatorial view and triangular-circular outline in polar view and usually striate exine sculpture type. These features in other genera of family Rosaceae were distinguished too by Reitsma (1967), Ueda and Tomita (1989), Hebda and Chinnappa (1990a, b), Xu and Yao (1991), Zhou et al. (1999), Radice et al. (2003), Arzani et al. (2005), Bednorz et al. (2005), Wrońska-Pilarek and Boratynska (2005), Wrońska-Pilarek et al. (2006), Dönmez (2008) and Polykova and Gataulina (2008).

The shape of pollen grains varies from subprolate through prolate. This feature is a characteristic feature that could separate two subgenera or two sections in the first subgenus in Iranian Amygdalus. The second subgenus, subgen. Dodecandra is delimitated regarding to pollen shape from the first one with prolate pollen grains (Table 2). Also, sect. Spartioides, with subprolate pollen grains in all taxa is distinguished from the first section in subgen. Amygdalus
(Table 2). The first section includes two vegetative groups (trees and shrubs). Regarding to pollen shape, tree subgroup is separated from the second one with prolate pollen grains (Table 2). In shrubby subgroup, two shapes are seen (Table 2).

Aperture form is an important feature of Rosaceae pollen. Tricolporate aperture is predominant (Hebda and Chinnappa 1990a). This aperture is compound consisting of colpus and pore as mentioned in Moore et al. (1991) for many members of Rosacceae. Tendency to pollen swelling is observed in the most studied species (Figs 3, 5, 17 and 31). Tendency to swelling was recorded in other genera of family Rosaceae including Crataegus (Dönmez 2008) that is a shrubby rosaceous member. As mentioned in the result part, the pollen wall in studied species is thin to average, also endoaperture is large (Fig. 2).This swelling is related to emerge of pollen tube that hydration level changes during this stage. Pollen grains with thin wall are more able to maintain the hydration. Normally, after acetolysis process and dehydration, these swelling parts disappear, but in our study, there were constant. In polish species of genus Rosa, operculum was observed in the central part of the ectocolpus (Wronska-Pilarek and Lira 2006) or in some species of Sanguisorba that are tricolporate operculate (Reitsma 1967). The operculum is visible (circular or elliptic) or invisible. According to Popek theory in 1996, the operculum covers the central part of the ectocolpus membrane and assumes the form of a substantial swelling with a sculpture as a rule similar to that of the mesocolpium (Wrońska- Pilarek and Lira 2006). Regarding to features of operculum in above, it is concluded that the swelling part on the ectocolpus in pollen grains of Amygdalus is not operculum and it is only a protoplasmic swelling.

Another pollen grain feature that considered as a main feature for separating of species in family Rosaceae is exine sculpture type, the most variable morphological charac- 
ter (Hebda and Chinnappa 1990a). The most frequent exine sculpturing in family Rosaceae is striate or striate-perforate (Ueda and Tomita 1989; Hebda and Chinnappa 1990a, b; Zhou et al. 1999; Dönmez 2008). Our results also showed this sculpturing type in most examined species with its subgroups (types I, II, V). While exine sculpture type could be a useful character for separating of taxa, in this study, exine sculpture is not able to delimitate two subgenera or two sections in the first subgenus in Iranian Amygdalus. Also in the first subgenus, there is enough difference between to vegetative groups or among species within shrubby group. The shrubby taxa in this subgroup or shrubs in the subgen. Dodecandra are the most heterogeneous taxa according to some pollen features such as: size of $\mathrm{P}$ and $\mathrm{E}$ axis, exine sculpture type, length of mesocolpium and ectocolpus, diameter of perforations, striae intervales and thickness of ridges. There is enough difference between closely related species like A. elaeagnifolia and A. reticulata (Table 2). It is interesting that two subspp. of A. elaeagnifolia (subgen. Amygdalus) or two varieties of A. lycioides (subgen. Dodecandra) exhibit different pollen characters such as exine sculpture type, colpi, striae and ridges characters (Table 2). Moore et al. (1991) have considered that pollen morphology in taxa of Rosaceae is very variable, even among the populations within the same species. Furthermore we found other exine sculpture types including rugulate, gemmate-perforate and reticulate (Figs 8, 12 and 24). Different exine sculptures were observed in some other genera of family Rosaceae including Turkish Crataegus (Dönmez 2008) and some rosaceous members in Canada (Hebda and Chinnappa 1990a). Another pollen features are striae intervals and ridges (muri) characters in pollen grains with striate sculpture type but unfortunately these characters could not separate taxonomic ranks in Iranian Amygdalus. For example, pollen grains with compact and dense striae are distributed in two subgenera specially in the first subgenus including A. wendelboi, A. korshinskyi, A. arabica (subgen. Amygdalus) and A. lycioides var. lycioides (subgen. Dodecandra).

From palynological point of view, an interesting feature was observed in A. Xiranshahrii. In this hybrid, there are two exine sculpture types including striate, type $\mathrm{V}$ and striate, type II-A (Figs 33-35). A. Xiranshahrii is a hybrid that was resulted from hybridization process between $A$. scoparia and A. eburnea. Exine sculpture in A. eburnea (one of the parents) is striate, type V like one of the sculpture types in this hybrid (Fig. 23). Comparison of other studied hybrids with their parents from palynological point of view show intermediate state more or less specially in exine sculpture .

\section{CONCLUSIONS}

With emphasis on our results in this study, among different pollen characters studied in Iranian Amygdalus taxa, the shape of grains are more useful for separating of taxonomic ranks in Amygalus solely. This feature could delimitate two subgenera, two sections in the first subgenus and two subgroups in the first section in this genus. Except the shape, unfortunately, other palynological characters specially exine sculpture type did not provide distinctive characters for delimitation of sections or two subgenera, so these characters are not of taxonomic values. Based on this research, we could not completely confirm previous morphological classification and taxonomic affinities in Iranian Amygdalus and this classic classification has not been supported. Maybe other studies including molecular investigations could help us to resolve taxonomic complexity in this problematic genus. Unfortunately there is not any molecular phylogenetic study about Iranian species of Amygdalus. All molecular studied on genus Prunus include a few species in subgen. Amygdalus (Lee and Wen 2001; Bortiri et al. 2001; Wen et al. 2008) that only one or two species of Amygdalus are found in Iran. Consequently, the phylogenetic importance of micromorphological studies can not be elavuated here.

\section{ACKNOWLEDGEMENTS}

We are very grateful to Dr. Khezri (Research Center of Agriculture and Natural Resources in Kurdistan province). We wish to thank Dr. Sh. Kazempoor Osaloo (Tarbiat Modarres University) for editing the manuscript. Also we thank Mrs. Eshghi (Islamic Azad University, Science and Research Branch) and Mr. Rahmani (Razi Metalorgy Research Institute) for providing SEM photos. This investigation received support from the research council at the University of Tehran (grant no. 6104009/1/04).

\section{LITERATURE CITED}

ARZANI K., NEJATIAN M.A., KARIMZADEH G. 2005. Apricot (Prunus armeniaca) pollen morphological characterization through scanning electron microscopy using multivariate analysis. New Zeland. J. Crop. Hort. Sci. 33: 381- 388.

BEDNORZ L., MACIEJEWSKA I., WROŃSKA-PILAREK D., FUJIKI T. 2005. Pollen morphology of the polish species of the Genus Sorbus L.. Acta Soc. Bot. Pol. 74(4): 315-322.

BORTIRI E., OH S.H., JIANG J., BAGGETT S., GRANGER A., WEEKS C., BUCKINGHAM M., POTTER D., PARFITT E. 2001. Phylogeny and systematics of Prunus (Rosaceae) as determined by sequence analysis of ITS and the chloroplast trnLtrnF spacer DNA. Syst. Bot. 26(4): 797-807.

BROWICZ K. 1969. Amygdalus. In: Rechinger K.H. (ed.), Flora Iranica, Rosaceae, Vol. 66. Akademische Druck und Verlagsanstalt, Graz, pp. 166-187.

BROWICZ K., ZOHARY D. 1996. The genus Amygdalus L. (Rosaceae): species relationships, distribution and evolution under domestication. Genet. Resour. Crop Ev. 43: 229-247.

DÖNMEZ E.O. 2008. Pollen morphology in Turkish Crataegus (Rosaceae). Bot. Helv. 118: 59-70.

ERDTMAN G. 1952. Pollen morphology and plant taxonomy. Almqvist \& Wiksell, Stockholm.

HALBRITTER H., WERBER M., ZETTER R., FROSCH-RADIVO A., BUCHNER R., HESSE M. 2007. Ilustrated Handbook on Pollen Terminology. http://www.paldat.org/paldat-Terminology- large.pdf.

HEBDA R.J., CHINNAPPA C.C. 1990a. Studies on pollen morphology of Rosaceae in Canada. Rev. Paleobot. Palynol. 64: 103-108.

HEBDA R.J., CHINNAPPA C.C. 1990b. Pollen morphology of the Rosaceae of western Canada. III. Geum. Can. J. Bot. 68(6): 1369-1378.

KHATAMSAZ M. 1993. Flora of Iran (Family Rosaceae). Vol. 6. Research Institute of Forests and Rangelands press, Tehran, pp. 274-315. 
MOORE P.D., WEBB J.A., Collinson M.E. 1991. Pollen Analysis. Blackwell scientific publications.

LEE S., WEN J. 2001. A phylogenetic analysis of Prunus and the Amygdaloideae (Rosaceae) using ITS sequences of nuclear ribosomal DNA. Am. J. Bot. 88(1): 150-160.

POLYKOVA T.A., GATAULINA G.N. 2008. Morphology and variability of the pollen of Spirea L. (Rosaceae) Genus in Siberia and the far east. Contemp. Probl. Ecol. 1(4): 420-424.

POTTER D., ERIKSSON T., EVANS R.C., OH S., SMEDMARK J.E.E., MORGAN D.R., KERR M., ROBERTSON K.R., ARSENAULT M., DIKINSON T.A., CAMPBELL C.S. 2007. Phylogeny and classification of Rosaceae. Pl. Syst. Evol. 266: 5-43.

PUNT W., HOEN P.O., BLACKMORE S., NILSSON S., LE THOMAS A. 2007. Glossary of pollen and spore terminology, Rev. Palaeobot. Palynol. 143 (1-2): 1-81.

RADICE S., ONTIVERO M., GIORDANI E., BELLINI E. 2003. Morphology and physiology of pollen grains of Italian Prunus persica (L.) Batsch cultivars grown in Argentina. Adv. Hort. Sci. 17(2): 93-96.

REISTMA T.J. 1967. Some aspects of the pollen morphology of the Genus Sanguisorba L. (Rosaceae). Rev. Palaeobot. Palynol. 4: 305-310.
UEDA Y., TOMITA H. 1989. Morphometric analysis of pollen exine patterns in Roses. J. Japan. Soc. Hort. Sci. 58(1): 211-220 .

WEN J., BERGGREN S.T., LEE C.H., ICKERT-BOND S., YI T.S., YOO K.O., XIE L., SHAW J., POTTER D. 2008. Phylogenetic inferences in Prunus (Rosaceae) using chloroplast $\mathrm{ndhF}$ and nuclear ribosomal ITS sequences. J. Syst. Evol. 46(3): 322-332.

WROŃSKA-PILAREK D., BORATYŃSKA K. 2005. Pollen morphology of Rosa gallica L. (Rosaceae) from southern Poland. Acta Soc. Bot. Pol. 74(4): 297- 304.

WROŃSKA-PILAREK D., MALIŃSKI T., LIRA J. 2006. Pollen morphology of polish species of genus Rubus - Part 1. Rubus gracilis. Dendrobiology 56: 69-77.

WRONSKA-PILAREK D., LIRA J. 2006. Pollen morphology of polish species of the genus Rosa - 1. Rosa pendulina. Dendrobiology 55: 65-73.

XU F., YAO Y.X. 1990. Observation on pollen morphology and exine ultrastructure of Pyrus in china. Chinese J. Bot. 3(1): 33$-41$.

ZHOU L.H., WEI Z.X., WU Z.Y. 1999. Pollen morphology of Prunoideae of China (Rosaceae). Acta Bot. Yunnan. 22(2): 207-211. 